\title{
Sanctions in Sport: The Relationship Between Legal and Local Regulation Sanciones en el deporte La relación entre la regulación legal y local
}

\author{
Inna Bolokan, Georgiy Samoylenko, Maxym Tkalych, Bogdan Panchenko, Volodymyr Dmytriv
}

Zaporizhzhia National University (Ukraine)

\begin{abstract}
Sports law is a relatively new phenomenon for jurisprudence in Ukraine. At present, there is no developed theoretical basis for responsibility in the field of sports in the domestic legal science. This publication is a study of world and national experience in solving this problem and is intended to be a source of further research in the field of sports law. The purpose of the study is to analyze the state of legal regulation of liability in the field of sports. The object of the study is the social relations that have developed in the field of sports law. The subject of the study is the public relations that have developed in the field of sports law in relation to legal and sports-competitive liability. Philosophical, general scientific and special scientific methods such as dialectical, system-structural, comparative-legal, and formal-legal methods acted as research methods. As a result of the work, the general features of legal regulation of sports sanctions in foreign countries were established, the terminology and conceptual schemes fundamental for legal doctrine were analyzed, the description of the state of research of the problem in the scientific environment is given, the national situation on responsibility in the field of sports is analyzed, typical examples of court cases in the researched aspect are specified, and also recommendations on improvement of the legal base are given.
\end{abstract}

Key words: liability, tort, disqualification, fine, doping.

Resumen: El derecho deportivo es un fenómeno relativamente nuevo para la jurisprudencia en Ucrania. En la actualidad, no existe una base teórica desarrollada para la responsabilidad en el campo del deporte en la ciencia jurídica nacional. Esta publicación es un estudio de la experiencia nacional y mundial en la solución de este problema y pretende ser una fuente de investigación adicional en el campo del derecho deportivo. El objetivo del estudio es analizar el estado de la regulación legal de la responsabilidad en el ámbito del deporte. El objeto del estudio son las relaciones sociales que se han desarrollado en el ámbito del derecho deportivo. El tema del estudio son las relaciones públicas que se han desarrollado en el ámbito del derecho deportivo en relación a la responsabilidad jurídica y competitiva deportiva. Actuaron como métodos de investigación métodos filosóficos, científicos generales y científicos especiales tales como métodos dialécticos, sistémicos-estructurales, comparativos-legales, formales-legales. Como resultado del trabajo se establecieron las características generales de la regulación legal de las sanciones deportivas en países extranjeros, se analizó la terminología y esquemas conceptuales fundamentales para la doctrina jurídica, se da la descripción del estado de la investigación del problema en el ámbito científico. , se analiza la situación nacional de la responsabilidad en el ámbito del deporte, se especifican ejemplos típicos de casos judiciales en el aspecto investigado, y también se dan recomendaciones sobre

\section{Introduction}

Starting with the most general, but almost the most important norm of legal regulation, which concerns the subject of research, it should be noted that Ukrainian legislation provides for the state to care for the development of physical culture and sports. The corresponding statement is contained in Art. 49 of the Constitution of Ukraine (1996).

The normative definition of sport as a concept we can find in the Law «On Physical Culture and Sports» (1993). According to Art. 1 of this legal act, sport - the activities of the subjects of physical culture and sports,

Fecha recepción: 28-10-20. Fecha de aceptación: 20-04-21

Maxym Tkalych

maxx.tkalich@gmail.com aimed at identifying and unifying comparisons of people's achievements in physical, intellectual, and other training through sports competitions and appropriate preparation for them. Art. 38 regulates the concept of professional sports, and in the third part, in particular, it is stated that the acquisition of the status of a professional athlete occurs from the moment of concluding a contract with the relevant subjects of physical culture and sports to participate in competitions among professional athletes.

We remember that the whole structure of the organization of Ukrainian sports can be divided into legal entities of commercial and non-commercial profile. They thus represent the private, public, or public aspect of the system of physical culture and sports. At the same time, it can be concluded that the Soviet sports system still prevails in Ukraine, where preference is given to the functioning of non-profit institutions, establishments 
or organizations, such as NGOs or sports federations, which significantly limits the development and capitalization of sports as such (Tkalych, \& Tolmachevska, 2020; Tkalych, 2009). Added to this problem is the fact that the issue of sanctions, or liability in sport, is not given enough attention by the legal environment to be considered as having an institutional framework for legal regulation, which leads to some issues such as the corruption component of sports investigations and, accordingly, their results; delimitation of the competence of the structures, which will be assigned the consideration of sports disputes, cases on what in the theoretical dimension is called the so-called sports and competitive liability; reasonableness of the type and size of sanctions, their expediency; the ability to review the decisions of sports organizations in court, etc.

So, at first glance, it may seem that the problem is insufficient legal regulation of this aspect of physical culture and sports as a responsibility, but before we come to the development of an extensive legal framework, it is necessary to answer general theoretical questions. Does sport need regulation? In what case will sports torts result in a mandatory court hearing? Where is the line between fair and inappropriate interference in the autonomy of sport? How do local and general legal regulation of this sphere of life relate? These and other questions need to be answered in the legal environment, and the factor of responsibility in the field of sport seems to be the best platform from which to start researching these interrelated issues.

\section{Material \& methods}

\section{Methodology}

The methodological basis of the study is composed of philosophical, general, and special scientific methods.

Thus, the dialectical method has found its manifestation in establishing the specifics of the legal regulation of sports sanctions at the international, national, and local levels, their formation, change, and development. This method of scientific knowledge allowed to analyze the institution of responsibility in sports in its development from punishment for violating the rules of the game to an extensive institution of legal and quasi-legal responsibility in sports with a complex system of sanctions provided by both legal and regulatory acts.

Besides, the system-structural method made it possible to formulate the main features of responsibility in the field of sports, the relationship, and interaction of legal norms on sports sanctions. This method allowed us to explore the institution of responsibility in sports in all the variety of connections, values, priorities that exist in the field of sports and jurisprudence. He allowed us to draw conclusions about the validity of maintaining the impact of soft law acts on participants in relations in the field of sports and maintaining a balance between the regulatory impact of legal and quasi-legal norms on relevant public relations in the context of sports and legal sanctions.

What is more, the application of the comparativelegal method was useful in analyzing the difference between liability provided by state coercion and local sanctions in sport, as well as it helped to identify differences between the legal norms of individual countries and within national legislation. The comparative-legal method allowed us to trace the general trends in the development of the institution of responsibility in Europe and in the world in general, which contributed to the development of approaches to reforming the institution in Ukraine.

Finally, the formal-legal method has proved its effectiveness in studying the content of legal norms on sports sanctions, establishing their advantages and disadvantages. In particular, this method helped to explore the true meaning of Art. 369-3 of the Criminal Code of Ukraine and draw conclusions about the need for its improvement.

\section{Análisis del estado de desarrollo científico del problema}

Foreign and domestic researchers have paid attention to issues related to or directly related to the topic of the work at different times, for example Anderson (2006), Cisneros (2020), Gearty (1985), Hock, and Gomtsian (2018), Ioannidis (2019), Rogers (2013), Amirov (2006; 2010; 2011), Bilyaev (2015), Margulis (2005), Nastavny (2018), Paholko (2015), Petrenko (2014), Popychev, Shapovalova, and Maslov (2014), Prokopets (2007).

Thus, Prokopets (2007) and Margulis (2005) in their works held the view that sports responsibility is nothing more than a kind of corporate because it is derived from the results of rule-making industry sports federations. Paholko (2015), on the contrary, notes that it is still a legal responsibility. Moreover, Bilyaev (2015) remarked that this type of responsibility involves its extension to members of sports organizations or related parties, so it has an internal nature. 
In addition, Amirov (2006) devoted most of his work to the issue of responsibility in the field of sports. The scientist divided the sports sanctions of local legal regulation into sports-technical and sports-disciplinary (material). He noted that such responsibility can also be considered legal because the rule-making of sports organizations is authorized by law (Amirov, 2010). What is more, he supported the use of the term «sports and competitive responsibility» (Amirov, 2011).

Regarding the measurement of criminal liability in sports, Petrenko (2014) considered a crime in the field of physical culture and sports a socially dangerous criminal act provided for by the Criminal Code of Ukraine, which harms or threatens to cause public relations that ensure the full development of physical culture and sports in the country and which, at the same time, are protected by the law on criminal liability.

Further, Gearty (1985) pointed to the growing problem of legal regulation of sports injuries due to criminal negligence in the mid-' 80 s of the twentieth century. In the article, the author analyzed the current materials of judicial practice, outlined the ways of development of legislation.

In his publication, Rogers (2013) criticizes the doctrine of immanent sports consent. The author points out that the practice of Anglo-Saxon courts is too diverse and contradictory in this aspect to be able to talk about a unified approach to the qualification of violations in the field of sports as socially dangerous crimes and further prosecution.

In the context of sports sanctions, foreign experts focused on issues related to the autonomy of sports, the feasibility of government intervention in the activities of sports institutions.

Anderson (2006) notes that, as a general rule, in England, courts resolve sports disputes based on the provisions of private law, given the contractual nature of the relationship between the parties. However, it is noted that some sports organizations may have the characteristics of public law institutions, as their decisions affect a wide range of people, and management methods are essentially public law.

A key point for Cisneros (2020) is the possibility of sports disputes to be considered in court, which provides for the jurisdiction of disputes involving sports governing bodies (SGBs) to judicial review (judicial review). Through a systematic, thorough, and step-by-step study, the author concludes that athletes and other participants in the field of sports, whose rights and responsibilities are affected by PSO decisions, on this basis should be guaranteed protection of their rights, freedoms, and interests in private, and in public. Corresponding results can be found in the works of domestic jurists (Nastavny, 2018; Popychev, Shapovalova, \& Maslov, 2014).

According to Ioannidis (2019), one of the possible ways to resolve the conflict between self-regulation within the sports environment and external influences, which are usually the responsibility of the judiciary, public authorities, etc., is to follow a clear direction of reforms within a single strategy on sanctions in three aspects: concerning unscrupulous sports agents (intermediaries), clubs, and entire federations.

In their article, Hock and Gomtsian (2018) conclude that the division between purely public and purely private means of influencing the sphere of sport and, consequently, the positive results of such activities are rather conditional conceptual schemes, which are inherent, first of all, in the doctrine appealed to by researchers, which in one way or another include supporters of self-regulation or private regulation, and fans of state control and intervention. This view is also held by Calliess and Zumbansen (2010), noting that each of the opposing camps is right in some way.

\section{Results}

International Practice of Applying Sports Sanctions as a Means of Legal Influence and acts of Local Regulation

\section{The experience of Germany}

The German legal doctrine in the studied aspect is characterized by significant fragmentation due to the separateness of each court decision on sports torts. Concerning sports injuries and the determination of the grounds for bringing a party to justice, a clear example is a decision of the Supreme Court (Bundesgerichtshof - BGH) VI ZR 100/73 of 05.11.1974 (DeJure, 2020), which states that every football player knowingly goes at risk of injury, even if you follow the rules of the game. Thus, the court must establish the fact of their violation in deciding on the issue of prosecution. It is noted that sometimes such a concept has been criticized in terms of its correlation with the principle of «venire contra factum proprium», because, according to the latter, the right of the injured athlete to protection by prosecuting the other party and awarding compensation was denied (Králik, 2015).This formula, known since ancient Rome, is reflected in continental law, which is characteristic not only of Germany but also of Belgium and the 
Netherlands. In its original form, it sounds like «non concedit venire contra factum proprium», which means «no one can act contrary to their previous behavior» (Tomarov, 2021). Thus, the application of this principle in practice would mean that the injured player denies the terms of the contract signed by him, according to which he agreed to the risk of sports injuries, which in turn is a violation of the principle of good faith and inadmissible conduct.

It is also worth noting that in the future the German courts concluded that there were no grounds for the prosecution not only in the case of compliance with the rules of the game but also in the case of minor or those covered by the principle of bona fide, i.e., «good will». This implies a distinction between breaking the rules, even if it has injured the victim, but which «fits into the logic of the game» and malicious, intentional, dishonest behavior, an act that goes beyond fair play, does not fit into the logic of confrontation, which in practice means that under equivalent circumstances the defendant would not have been able to suffer similar damage. Such conclusions are contained in the ruling of the Higher Labor Court in Cologne (LAG Kõln) from 28 June 1984, file no. 10 Sa 59/84. We find something similar in the decisions of the Regional Court (LG) of Bielefeld from 8 January 2001, file no. 4 O 156/00 and Higher Regional Court (OLG) of Düsseldorf from 2 April 2004, file no. I-14 U 230/03, in which courts appeal to the competitive nature of a particular sport, which often manifests itself in fierce skirmishes and confrontations. Thus, we can conclude that the German legal doctrine is characterized by the provision of significant discretionary powers of the court in deciding on the application of liability in cases of sports disputes, in particular, concerning sports injuries.

Related doctrinal considerations and some examples of liability regulation in other countries

It is also possible to ignore the fact that in all similar cases the plaintiff will have to justify first that the defendant had a duty of care, and as a result of his violation the plaintiff was harmed. At the same time, such an act must go beyond the specific risk specific to a particular sport, so it must have such features as a malicious intentional violation and gross neglect of the safety of the victim. For example, in the case of Nabozny v. Barnhill (1975). The goalkeeper of one of the teams was injured by a player of the opposing team. According to the circumstances of the case, the incident occurred when the ball was in the hands of the goalkeeper, and he was within his penalty area. Despite fixing the ball in the goalkeeper's hands, the defendant disregarded football rules and safety by kicking the plaintiff in the head. The Court of Appeal found the defendant guilty of committing this offense and ordered to recover damages in favor of the plaintiff.

The application of sanctions in sports in Brazil and France is enshrined in law. The relevant codes (Código Brasileiro de Justiça Desportiva (Gov.br., 2021), Le Code du Sport Français (2004)) contain rules on the tort capacity of athletes in the event of gross violations, establish the powers of institutions and organizations to prosecute.

According to FIFA (2009) rules, a football referee is a primary link among the subjects of sports sanctions. It is known that a referee on the field may apply disciplinary measures in the form of a warning («yellow card»), removal («red»), both to players and coaches or other team members.

\section{Anti-doping regulation}

It should be noted that sanctions for doping are no less important. The main acts of legal regulation in this aspect are the International Convention for the Suppression of Doping in Sport (November 18, 2005, Paris), and the Code of the World Anti-Doping Agency (WADA) (2017). These documents define the range of concepts crucial for anti-doping control, provide a list of prohibited substances, authorize specific organizations to implement anti-doping measures. The effectiveness and efficiency of both these international agreements and the organizations identified by them are confirmed by factual data. Thus, according to the WADA (2015) report (Figure 1), in 2015, the most violations were recorded by the Russian Federation (176 cases), and the sport in which it occurred most often was bodybuilding (270) (Figure 2). It should be added that, as a result, on December 9, 2019,WADA will ban Russia from participating in the Olympic Games and other major international competitions (Church, \& Morse, 2019), and the Russian Anti-Doping Agency (RUSADA) will appeal the decision to the Court of Arbitration for Sport, CAS) in Lausanne, Switzerland (Church, 2019).

Detailing the activities of WADA (2018), we note that its Code has been recognized by more than 700 sports organizations around the world. It contains 6 Standards for different areas of application, and from January 1, 2021, will be supplemented by two more. Adoption, implementation, and (right) of application are the three main steps for any organization on the 


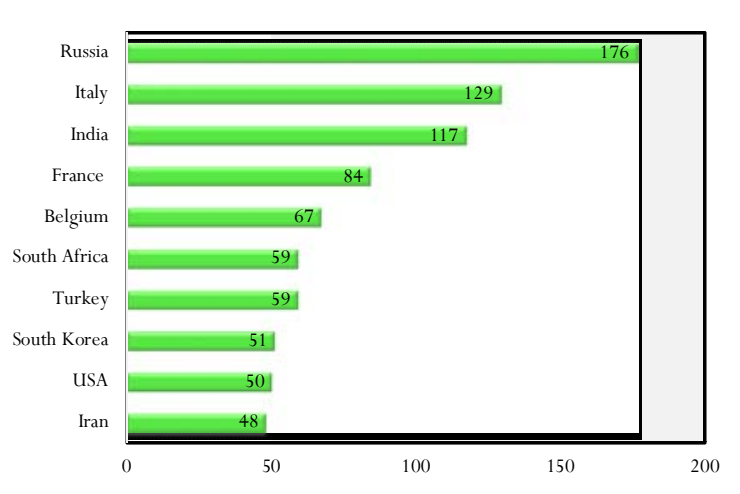

Figure 1. Countries with the most anti-doping violation, number of cases as of 2015. Data provided by WADA (2015), https://www.wada-ama.org

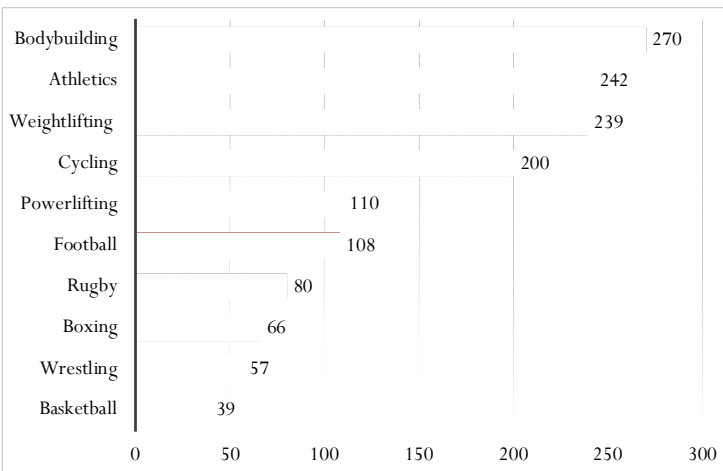

Figure 2. Sports with the most anti-doping violations, number of cases as of 2015. Dat provided by WADA (2015), https://www.wada-ama.org

way to full compliance with WADA standards. A special monitoring mission monitors the progress of the implementation of the Code.

In its activities, WADA (2017) is guided by the principle of strict liability. It implies that if the athlete's body detects prohibited substances, their markers or metabolites, the burden of proving how - intentionally, negligently, or accidentally - they got to him/her, falls entirely on the shoulders of the person accused of doping. The consequence of obtaining a positive doping test during the competition is the annulment of the results of the guilty athlete. In case the commission or other authorized body proves the accidental entry of prohibited substances, their markers or metabolites into the athlete's body, the application of sanctions may be reduced or revoked (Article 10 of the Code (WADA, 2018)), whether it can, to the satisfaction of the court, determine how the substance entered his system, demonstrate that he or she was not at fault or substantially guilty or, in certain circumstances, did not intend to improve his or her athletic performance. This means that the burden of proof rests with the athlete. The principle of strict liability set out in the Code has been consistently upheld in the rulings of the Court of Arbitration for Sport (CAS) and the Swiss Federal Court.

At the expense of CAS, it should be noted that, unlike the European Court of Justice and the European
Court of Human Rights, which are regional institutions, CAS is an international arbitration specializing in sports disputes of a disciplinary and substantive nature (Reilly, 2012). Nevertheless, the CAS review system has been criticized for the high cost of litigation and sponsorship by major sports federations.

\section{Discussion}

\section{Doctrinal aspect}

This section should begin with the fact that, in general, the sports law of foreign countries is not characterized by features that would make it fundamentally different from other spheres of human life. Sanctions in sports, the application of liability revolve around such categories as tort, negligence, and so on. Therefore, it cannot be said that the approach to the legal regulation of this area is unique. It should be noted that the field of sports combines both elements of legal and quasi-legal regulation. This means that in addition to legal norms for the regulation of certain types of relations, soft law acts are used that are not universally binding. This approach is typical of private law, because it is private law that allows you to regulate relations at the contractual level, i.e. to apply self-regulation as opposed to legal regulation. In general, it is private law that can most effectively regulate most public relations. The field of sports is no exception to this rule.

Along with soft law acts foreign countries are characterized by the consistency of the methods of legal influence in the field of sports with the techniques and methods that are characteristic of their national legal systems in general. Important theoretical and legal concepts here are the so-called doctrine of assumption of risk, or, as it is also called, the doctrine of implied sporting consent or consent of harm. Its meaning is that sport is essentially an activity that carries specific risks of adverse consequences in the form of injuries, temporary disability, or even disability, so athletes consciously go for them, for example, when signing a contract, which then becomes the subject of consideration in court, if the dispute cannot be settled in another way and the contract or other legal norm allows such appeal (Dickson, 2020).

Theoretical and normative-legal basis for the application of responsibility in the field of sports in the legal field of Ukraine, as well as at the level of local regulation (statutes, regulations, rules of sports organizations) 
Unfortunately, in Ukraine, there is still no clear state policy in the field of sports, which would provide for a program of reforming domestic sports taking into account the current world trends. The result of such an approach to the sports sector is a gradual decline in the performance of Ukrainian athletes and the decline of the sports infrastructure (Tkalych, Davydova, \& Tolmachevska, 2020). No other social norms, such as traditions, customs, norms of morality, etc., are able to regulate and ensure the protection of various social relations as the rules of law do (Tkalych, Safonchyk, \& Tolmachevska, 2020). Sports law is still prematurely recognized as an independent legal order, because the very term «legal order» implies the existence, first of all, of legal norms. In this case, the law-making function should belong to public authorities (Kharytonov, Kharytonova, Kostruba, Tkalych, \& Tolmachevska, 2021).

According to Art. 54 of Law No. 3808-VII (On physical culture and sports, 1993), persons guilty of violating the law in the field of physical culture and sports, bear civil, disciplinary, administrative, or criminal liability under the law.

Among the materials of national jurisprudence are examples of resolving cases in different branches of law depending on the type of legal liability (hereinafter LL). In the field of civil law, cases of compensation for damage to health (Case No. 6-693sv09, 2009), compensation for damages (Case No. 522/3337 / 14t, 2004) prevail. For offenses that encroach on public order or pose a significant public danger, administrative or criminal liability is provided, so most often related to the sports sphere are corruption offenses or crimes, misappropriation of funds of a sports organization (Case No. 5-824km15, 2014), hooliganism, discrimination (Case No. 801/4018/13-a, 2013), social, racial, national, and religious enmity, etc. In the field of labor law, there are also violations of payroll (Case No. 334/347/13-ts, 2013; Case No. 22-5526 / 10, 2012).

Section 3 of the Law No. 3673-VI (On features of maintenance of a public order and public safety in connection with preparation and carrying out of football matches, 2011) regulates sanctions for violation of the requirements of the legislation on public order and public safety in connection with the preparation and holding of football matches.

\section{Criminal liability}

According to Art. 369-3 of the Criminal Code of Ukraine (2001) (hereinafter - the Criminal Code), it can be stated that it implies the application of sanctions for two independent manifestations of punished behavior:

1) influence on the results of official sports competitions (hereinafter - OSC) and obtaining illegal benefits as a result of such acts, 2 Article 369-3 of the Criminal Code);

2) violation of the ban on placing bets on sports (Part 3 of Article 369-3 of the Criminal Code) (Zadoya, 2015).

Thus, the title, which is given in the Criminal Code («Illegal influence on the results of official sports competitions»), does not actually mention the type of criminal behavior specified in Part 3 of Art. 369-3 (Zadoya, 2015).

In addition, the legal components of the crimes under Part 1 of Art. 369-3 and Part 2 of Art. 369-3 of the Criminal Code, are correlated as basic and qualified, and defined in Part 3 of Art. 369-3 is independent (Zadoya, 2015). Therefore, on an objective basis, it is necessary to differentiate the impact on the results of OSC to obtain an improper benefit and its resulting.

From the subjective side of the crimes under Part 1, 2 of Art. 369-3 of the Criminal Code these actions are characterized by direct intent. It should also be emphasized that we are talking only about OSC within the meaning of Art. 1 of Law No. 743-VIII (On prevention of influence of corruption offenses on results of official sports competitions, 2015). Qualifying features of the offense under Part 1 of Art. 369-3 of the crime is its commission concerning OSC of minors or repeatedly that is provided by p. 2 Art. 369-3. According to the logic of the legislator, bribery, coercion, incitement, and conspiracy are an exhaustive list of ways to influence the results of OSC.

A special entity (athletes; sports support staff participating in a sporting event; sports officials) will only be involved in the case of passive bribery. For all other ways of influencing the subject is common (Zadoya, 2015). However, some researchers prefer not to focus on this and prefer a literal interpretation of the note of Art. 369-3 of the Criminal Code (Bantishev, 2018).

Concerning the violation of the ban on sports betting, it should be noted that this type of illegal behavior refers to crimes with material composition, which implies obtaining an illegal benefit for themselves or others in the amount exceeding twenty subsistence minimums for able-bodied persons the prohibition object (athletes; support staff participating in a sporting event; sports officials) bets on a sporting event with his or her participation or with the participation of his or her team to obtain such a benefit. 
The objective side of the crime is the actions of a person committed in a way that violates the prohibition established by Part 4 of Art. 8 of Law No. 743-VIII. Thus, we can identify several features that are necessary to establish the composition of this crime. These include the presence of direct intent, the receipt of illegal property benefits, and the participation of a special entity. In the end, it is necessary to emphasize that at the establishment inactions of the person of corpus delicti at the same time under p. 1, 2, 3 Art. 369-3 of the Criminal Code, their ideal set will take place.

The main problem of criminal liability for sports corruption is the application of Art. 369-3 of the Criminal Code of Ukraine. Thus, at the time of writing, there is no conviction under this article. This calls into question its effectiveness (Kolomoiets, Tkalych, Melnyk, Panchenko, Tolmachevska, 2021).

Criminal liability is also provided for inducing minors to use doping (Article 323 of the Criminal Code). The composition of the crime involves the intentional encroachment of an adult convicted person on the health, normal development of the victim, who has not reached 18 years of age, regardless of his gender or attitude to sports (On the application by courts of legislation on liability for the involvement of minors in criminal or other anti-social activities, 2004). Doping, or, prohibited by the Olympic Movement Anti-Doping Code, substances and techniques used to improve performance and risk harm to the health and normal functioning of the body may act as a means of committing a crime in some cases. Qualifying features are the commission of this crime by a special subject, or repeatedly (Part 2 of Article 323). Particularly qualifying is the commission of two or more persons, or if the damage to health, or if it is significant, or the commission of a crime has led to other serious consequences.

\section{Anti-doping}

Art. 9 of the Law No. 1835-VIII (On anti-doping control in sports, 2017) establishes liability for violations of anti-doping legislation. According to her, violations are established following anti-doping rules. The authorities responsible for this procedure are the National Anti-Doping Center or another anti-doping organization. Sanctions are applied under the anti-doping rules and the Convention. On the example of this legal norm, the question may arise: is the responsibility for violating sports rules primary or secondary to the law? We believe that given the principle of autonomy of sport, it is primary, because if you use the method of reasoning from the opposite, first, the statutory sanctions would have nothing to rely on, and secondly, sports regulations, statutes, and rules would still provide for responsibility and would act at the local level.

\section{Sports or sports-competitive responsibility}

Such responsibilities as a disqualification, fines, deprivation of surcharges, ban on fans to participate in team support, ban on transfer activities, transfer to the lower league, withdrawal of points, deprivation of medals, etc., give scientists a reason to discuss the allocation of so-called «sports» or «sports-competitive» liability (SCL) as an independent species. This concept is supported by the fact that some types of restrictions, such as disqualification due to violations of the rules of the game, are not a measure of state coercion. Nevertheless, there are cases when sports sanctions acquire signs of legal responsibility, so they go beyond independent tort. For example, a violation of the UEFA Disciplinary Rules, which resulted in litigation (Case No. 2010/6340/12, 2013; Case No. 2020/4580/2012, 2012;Tikhonova, 2018).

In the context of high-profile sports scandals, it is necessary to mention the case of the contractual match of Kharkiv's «Metalist» against Lviv's «Karpaty» on April 19, 2008, with a score of 4:0 (BBC News, 2013). In August 2010, the Control and Disciplinary Committee of the Football Federation of Ukraine imposed a fine of $\$ 25,000$, and two months later the Appeals Committee imposed disqualification sanctions on those involved (Liga. News, 2013). After that, the clubs appealed to CAS, but no avail. On August 2, 2013, the arbitration approved a wide list of sanctions, including a club fine of \$ 25 thousand, deprivation of Kharkiv bronze of the Ukrainian Premier League season 2007/2008, different terms of disqualification of players and officials, and fines of $\$ 10$ thousand each (CAS, 2013). Lviv officials were a little more fortunate: their leaders were given suspended disqualifications, halved and quadrupled fines, and the Karpaty director general's complaint was upheld in full, freeing him from any sanctions. Because of this, on August 14 UEFA suspended the Kharkiv club from participating in the European Cups. Metalist again complained to CAS, which refused. On August 16, the Kharkiv club's lawyers appealed to the Swiss Supreme Court, which suspended the arbitration court's ruling. On August 20, CAS denied this, and on August 28, 2013, made a final decision, depriving Metalist of the right to participate in the European Cups of the 2013/2014 season (Day, 2013). 
There are also well-known cases of imposing sanctions on sports clubs for violating the procedure for payment of wages. It should be noted that it is not uncommon for a specialized agency, such as the UEFA Club Financial Control Authority, to decide on the application of such restrictions. Bright examples are the termination of such teams as FC «Arsenal» Kyiv (InterFax, 2012; UEFA, 2013), «Metallurg» (Donetsk), «Kryvbas» (Kryvyi Rih), «Tavria» (Simferopol), «Sevastopol», «Metallurg» (Zaporizhzhia). All of them were somehow liable for the accumulation of debts and non-fulfillment of their obligations, which eventually led to their insolvency (Koshevarov, 2017). For the same reason, FC Dnipro was not admitted to the European Cup competitions of the 2016/2017 season (UEFA Club Financial Control Body. Adjudicatory Chamber, 2016). We remember that the problems of salary arrears were constantly accompanied by Lviv «Karpaty» (Football24, 2014).

In his works, Bilyaev (2015) cites the obligatory features of sports responsibility, which include the obligatory correlation with competitions, the consequences in the form of giving preference to the opponent of the sanctioned entity, which is most often sports organizations, such as clubs, and the subject of the decision on the application of sports and competitive liability - a judge (referee, arbitrator). We believe that this approach can be characterized as narrow, with its advantages and disadvantages, which, on the one hand, include the specification of the cases that constitute the independence of the SCL, on the other hand, ignore the processes that are concomitant, relevant, or simply preparatory to the competition, such as that which takes place during training, as well as the organization and conduct of the competition itself and the role of officials, members of staff or other officials in it. Also, the separation of the subject of appointment as a referee or arbitrator is confusing, because the mandatory nature of this feature in the structure of the SCL is nothing more than the usual refereeing in the field. From this point of view, handball, the appointment of a penalty, «yellow» or «red» card, etc. make sense only within the «logic of the game», and outside it acts only as circumstances of the case, i.e., independent legal burden, which is characterized by LL, do not carry.

\section{Conclusions}

As a result of this work, we can draw the following conclusions:

1. The issue of sanctions in the field of sports from the point of view of legal regulation needs further scientific development. International experience shows that one way or another, similar problems have appeared in the past in almost every country with a developed legal system.

2. There is a clear link between the doctrine inherent in individual legal systems and the ways or approaches to solving problems in the field of responsibility in the field of sport. Thus, countries with a prevailing AngloSaxon model tend to be guided by the development of case law, while countries of the Romano-Germanic legal family tend to standardize and codify legal norms that will help regulate liability.

3. Concerning the application of sanctions in Ukrainian sports from a legal point of view, it seems appropriate to first determine the organizational basis for the functioning of the sports industry, to formulate priorities for its existence, in particular, at the doctrinal level. As we see that in its current form, within the modern model of Ukrainian sports, there are many cases of violations of various kinds (contract matches, detention or non-payment of wages, racism, hooliganism, etc.), we are forced to state that it is at least one that requires significant improvement.

4. Given the principle of sports autonomy, however, it cannot be concluded that the Ukrainian legal system should use the principle «everything that happens on the field remains on the field» without any deviations or remarks. Obviously, if a program is developed at the legislative level that will help liberalize the industry and capitalize on its actors, we will sooner or later face the need to take into account and seriously consider the experience of foreign countries that have successfully got rid of over-regulation and bureaucratization.

5. It also seems fair that, summarizing the international experience on sanctions in sports and their expression at the level of legal and local regulation, we can conclude that one way or another, but as for sports corruption offenses and ignoring the requirements of labor law, or the abuse of civil rights, or the infliction of substantial damage to health, or other serious consequences as a result of a sports injury, these acts, going beyond the socially acceptable, should be the subject of litigation, so it is extremely important to strike a balance between sports autonomy and maintaining the rule of law, which, of course, should become one of the principles of the future codified act in the field of sports law in Ukraine if society and the legislator will conclude that it is necessary to adopt it. 


\section{References}

Amirov, I.M. (2010). Features of legal responsibility in the field of sports: to the problem statement. Society and Law, 4(31), 120-126.

Amirov, I.M. (2006). Legal responsibility in the field of sports (theory and practice). Ufa: UYUI Ministry of Internal Affairs of the Russian Federation.

Amirov, I.M. (2011). Special legal responsibility in the field of sports. Sports law: development prospects, 1, 2832.

Anderson, J. (2006). An Accident of History: Why the Decisions of Sports Governing Bodies are Not Amenable to Judicial Review. Common Law World Review, 35(3), 173-196. doi: 10.1350/ clwr.2006.35.3.173.

Bantishev, O.F. (2018). Criminal-legal struggle against corruption in sports. Criminal law and criminology, 1(36), 9-13. DOI: 10.31359/2222-5544-2018-36-19.

BBC News. (August 2, 2013). The court in Lausanne recognized the match between Metalist and Karpaty as a match fixing. Retrieved from: https:// www.bbc.com/ukrainian/sport/2013/08/ 130802_metalist_karpaty_ek.

Bilyaev, O.O. (2015). Sports organizations as subjects of civil law. Kharkiv: Yaroslav Mudryi National University of Law. Retrieved from: http:// nauka.nlu.edu.ua/download/diss/Bilyaev/ d_Bilyaev.pdf.

Calliess, G.-P., \& Zumbansen, P. (2010). Rough consensus and running code: a theory of transnational private law. Oxford: Hart Publishing.

CAS. (2013). CAS issues its decision in the case FC Karpaty and FC Metalist (Ukraine). Retrieved from: https://web.archive.org/web/20131015094713/ http: / /www.tas-cas.org/d2wfiles/document/

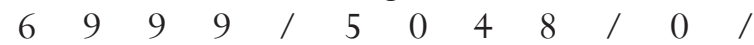
Media20Release20_English_20Metalist.pdf.

Church, B. (December 19, 2019). Russia to appeal against four-year doping ban. CNN Sports. Retrieved from: https://edition.cnn.com/2019/12/19/sport/ russia-doping-wada-ban-appeal-spt-intl/ .

Church, B., \& Morse, B. (December 10, 2019). Russia banned from 2020 Olympics and 2022 World Cup over doping scandal. CNN Sports. Retrieved from: https://edition.cnn.com/2019/12/09/sport/ wada-ban-russia-decision-rusada-doping-spt-intl/ index.html.

Cisneros, B. (2020). Challenging the call: Should sports governing bodies be subject to judicial review? The
International Sports Law Journal, 20, 18-35. Retrieved from: https://doi.org/10.1007/s40318-020-001659

Day. (April 23, 2013). Metalist was finally denied an appeal. Retrieved from: https://m.day.kyiv.ua/uk/ news/280813-metalistu-ostatochno-vidmovili-uapelyaciyi.

DeJure. (2020). Jurisprudence: BGH, 05.11.1974 VIZR 100/73. Retrieved from: https:// dejure.org / dienste / vernetzung /

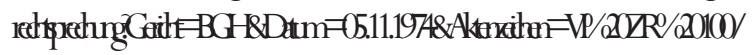
73.

Dickson, A. (January 31, 2020). Sports injuries: a risky business. How does the law look at negligence in the sporting world? Retrieved from: https:// w w w. ha r p e r m a c l e od. co.uk/ 500.htm?aspxerrorpath $=/ \mathrm{hm}$-insights $/ 2015 /$ september/sports-injuries-a-risky-business-howdoes-the-law-look-at-negligence-in-the-sportingworld/

FIFA. (2009). Game rules. Retrieved from: http:// pfl.ua/docs/FIFA_Rules_of_the_Game\%28200809\%29.pdf.

Football24. (October 24, 2014). Fedetsky and Milosevic's lawyer: Perhaps the management of Karpaty wants to close the club with other people's hands. Retrieved from: https://football24.ua/

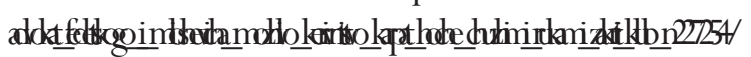

France. (2004). Le code du sport français. Retrieved from: https://www.legifrance.gouv.fr/codes/ texte_lc/LEGITEXT000006071318/

Gearty, C. (1985). Tort: Liability for Injuries Incurred during Sports and Pastimes. The Cambridge Law Journal, 44(3), 371-373. Retrieved from: www.jstor.org/ stable/4506778.

Germany. Bielefeld district court. (2001). Judgment 40 156/00. Retrieved from: https://www.juris.de/ jportal/prev/KORE542522002.

Germany. Dusseldorf Higher Regional Court. (2004). Judgment I-14 U 230/03. Retrieved from: https:// dejure.org / dienste / vernetzung /

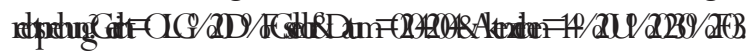

Germany. Regional Labor Court of Cologne. (1984). Judgment 10 Sa 59/84. Retrieved from: https:// research.wolterskluwer-online.de/document/ ab8967c8-2c18-4634-92f4-be7e3b299dea.

Gov.br. (2021). Nódigo Brasileiro de Justiça Desportiva. Retrieved from: http://www.esporte.gov.br/ seminarioreformacodbrasileiro/arquivos / cbjdFinal.pdf. 
Hock, B., \& Gomtsian, S. (2018). Private order building: the state in the role of the civil society and the case of FIFA. International Sports Law Journal, 17, 186204. Retrieved from: https://doi.org/10.1007/ s40318-018-0123-1.

InterFax. (December 21, 2012). UEFA's Arsenal in Kyiv has fined EUR75,000 for violating «financial fair play». Retrieved from: https: / / ua.interfax.com.ua/news/ sport/133033.html.

Ioannidis, G. (2019). Football intermediaries and selfregulation: the need for greater transparency through disciplinary law, sanctioning and qualifying criteria. The International Sports Law Journal, 19, 154 170, Retrieved from: https://doi.org/10.1007/ s40318-019-00159-2.

Kharytonov, E., Kharytonova, O., Kostruba,A., Tkalych, M., \& Tolmachevska, Y. (2021). To the Peculiarities of Legal and Non-Legal Regulation of Social Relations in the Field of Sport. Retos, 41, 131-137. Retrieved from: https:// recyt.fecyt.es/index.php/retos / index

Kolomoiets, T., Tkalych, M., Melnyk, P., Panchenko, B., Tolmachevska, Y. (2021). Combating Corruption in Sport: Legal Aspect. Retos, 41, 746-755. Retrieved from: https: / / recyt.fecyt.es/index.php/retos / article/view/86975

Koshevarov, O.L. (2017). The impact of club licensing and financial control systems on the competitiveness of European football clubs. Effective economy, 2, 1-14. Retrieved from: http:// www.economy.nayka.com.ua/?op $=1 \& z=5447$.

Liga. News. (August 28, 2013). Lausanne's court has finished hearing Metalist's appeal. Retrieved from: https:/ / ua-news.liga.net/sport/news / sud_lozanni_zak_nchiv_rozglyadati_apelyats_yu_metal_sta.

Margulis, M.A. (2005). Rule-making of corporate associations in the field of sports. Moscow: Moscow State Law Academy.

Nastavny, I. (2018). Legal status of a professional athlete as a major participant in professional sports relations. Entrepreneurship, economy and law, 9, 24-28.

Pakholko, S.V. (2015). The ratio of sports disciplinary responsibility and legal responsibility in sports. Collection of scientific articles of students, undergraduates, graduate students, 14, 61-63.

Petrenko, O.I. (2014). Concepts and types of crimes in the field of physical culture and sports. Forum of Law, 1, 406-411. Retrieved from: http://nbuv.gov.ua/jpdf/FP_index.htm_2014_1_71.pdf.

Popychev, M.I., Shapovalova, O.A., \& Maslov, V.M. (2014). Problematic issues of legal regulation of professional sports. Bulletin of Chernihiv National Pedagogical University. Pedagogical sciences. Physical education and sports, 118(1), 282-285. Retrieved from: h t t p : / / n b u v. gov.u a / j - p d f / VchdpuPN_2014_118(1)_63.pdf.

Prokopets, M.A. (2007). Sporting responsibility and sporting sanctions. Sports Law: Development Prospects, 1, 131-135.

Reilly, L. (2012). An introduction to the Court of Arbitration for Sport (CAS) \& the role of national courts in international sports disputes. Journal of Dispute Resolution, 1, 63-82. Retrieved from: https:/ /scholarship.law.missouri.edu/jdr/vol2012/iss1/5/

Rogers, M. (2013). À critical analysis of the doctrine of implied sporting consent. Criminal, Sports Law, 1, 110. Retrieved from: https:// sportslawmatt. wordpress.com/2013/12/01/acritical-analysis-of-the-doctrine-of-implied-sportingconsent/.

TheWorldAnti-Doping Agency (WADA). (2018). World Anti-Doping Code (2015, with 2018 amendments). Retrieved from: https://www.wada-ama.org/ sites / default/files/resources / files / wada_antidoping_code_2018_english_final.pdf.

The World Anti-Doping Agency. (2017). Strict liability in anti-doping. Retrieved from: https: / / www.wadaama.org/en/questions-answers/strict-liability-inanti-doping.

Tikhonova, M.A. (2018). Legal responsibility in the field of sports. Legal Journal of Donbass, 3(64), 55-60. DOI: 10.32366/2523-4269-2018-64-3-55-60.

Tkalych, M., \& Tolmachevska, Y. (February 3, 2020). Sport, sport, sport... Is there a prospect of institutional development? Legal Newspaper online. Retrieved from: https://yur-gazeta.com/ publications/practice/sportivne-pravo/sport-sportsport-chi-e-perspektiva-instituciynogo-rozvitku.html.

Tkalych, M., Davydova, I., \& Tolmachevska, Y. (2020). Current State and Prospects of Development of the Sports System of Ukraine: Legal Aspects. Retos, 38 , 385-389. Retrieved from https://recyt.fecyt.es/ index.php/retos/article/view/76997

Tkalych, M., Safonchyk, O., \& Tolmachevska, Y. (2020). Private Law and human rights: New realities. DIXI, 32, 1-12. DOI: https://doi.org/10.16925/23575891.2020.02.04

Tkalych, M.O. (2009). Sports clubs as participants in civil law. Îdesa: National University «Odesa Law Academy». 
Tomarov, I. (December 19, 2021). Fantastic estopels and where to look for them in Ukraine. Legal Newspaper online. Retrieved from: https://yurgazeta.com/dumka-eksperta/fantastichni-estopelita-de-yih-shukati-v-ukrayini.html.

UEFA Club Financial Control Body. Adjudicatory Chamber. (2016). Order in case AC-07/2015 LLC Football Club Dnipro. Retrieved from: https:/ / www.uefa.com/MultimediaFiles /Download/ OfficialDocument/uefaorg/ClubFinancialControl/ 02/34/91/70/2349170_DOWNLOAD.pdf.

UEFA. (2013). Financial Control Institution solutions. Retrieved from: https://bit.ly/2HVNBN7.

Ukraine. (1993). On physical culture and sports: Law 3808-XII. Retrieved from: https:// zakon.rada.gov.ua/laws/show/3808-12\#Text.

Ukraine. (1996). Constitution. Retrieved from: https: / /zakon.rada.gov.ua/laws/show/254\%D0\%BA/96$\%$ D0\%B2\%D1\%80\#Text.

Ukraine. (2001). Criminal Code of Ukraine. Retrieved from: https: / / zakon.rada.gov.ua/laws/show/234114/print1485262012336407\#Text.

Ukraine. (2015). On prevention of influence of corruption offenses on results of official sports competitions: Law 743-VIII. Retrieved from: https: / /zakon.rada.gov.ua/laws/show/743-19\#Text.

Ukraine. (2017). On anti-doping control in sports: Law 1835-VIII. Retrieved from: https:// zakon.rada.gov.ua/laws/show/1835-19\#Text.

Ukraine. Derhachiv District Court of Kharkiv Region. (2013). Case No.2010/6340/12. Unified state register of court decisions. Retrieved from: http:// www.reyestr.court.gov.ua/Review/29528667.

Ukraine. District Administrative Court of the Autonomous Republic of Crimea. (2013). Case No. 801/4018/13-a. Unified state register of court decisions. Retrieved from: http:// www.reyestr.court.gov.ua/Review/32227138.

Ukraine. Kominternivsky District Court of Kharkiv. (2012). Case No. 2020/4580/2012. Unified state register of court decisions. Retrieved from: http:/ /www.reyestr.court.gov.ua/Review/24865900.

Ukraine. Leninsky District Court of Zaporizhia. (2013). Case No.334/347 / 13-ts. Unified state register of court decisions. Retrieved from: http:// www.reyestr.court.gov.ua/Review/33132422.

Ukraine. Panel of Judges of the Judicial Chamber for Civil Cases of the Court of Appeal of Zaporizhia Oblast. (2012). Case No. 22-5526 / 10. Unified state register of court decisions. Retrieved from: http: /
/www.reyestr.court.gov.ua/Review/11178714.

Ukraine. Panel of Judges of the Judicial Chamber for Criminal Cases of the High Specialized Court of Ukraine for Civil and Criminal Cases. (2014). Case No. $5-824 \mathrm{~km} 15$. Unified state register of court decisions. Retrieved from: http:// www.reyestr.court.gov.ua/Review/44294231.

Ukraine. Primorsky District Court of Odessa. (2014). Case No.522/3337 / 14ts. Unified state register of court decisions. Retrieved from: http:// www.reyestr.court.gov.ua/Review/40193442.

Ukraine. Supreme Court of Ukraine. (2004). On the application by courts of legislation on liability for the involvement of minors in criminal or other antisocial activities: Resolution 2. Retrieved from: https: / / zakon.rada.gov.ua/laws/show/v000270004\#Text.

Ukraine. The Board of Judges of the Judicial Chamber for Civil Cases of the Supreme Court of Ukraine. (2009). Case No. 6-693sv09. Unified state register of court decisions. Retrieved from: http:// www.reyestr.court.gov.ua/Review/4299598.

Ukraine. (2011). On features of maintenance of a public order and public safety in connection with preparation and carrying out of football matches: Law 3673-VI. Retrieved from: https:// zakon.rada.gov.ua/laws/show/3673-17\#Text.

UNESCO. (2005). International Convention for the Suppression of Doping in Sport. Retrieved from: http: / / portal.unesco.org / en / ev.php$U \mathbb{R} \_\mathbb{D}=31037 \& \mathbb{R} L \_$DO=DO_TOAC\&URL_ECTION=201/hm

USA. Circuit Court of Cook County. (1975). Nabozny v. Barnhill. Retrieved from: http://il.findacase.com/ research / w frm Doc Viewer. aspx / xq / fac.19750723_0001050.IL.htm/qx.

WADA. (April 3, 2015). 2015 Anti-Doping Rule Violations Report. Retrieved from: https: / / www.wada-ama.org/en/media/news/2017-04/ wada-publishes-2015-anti-doping-rule-violationsreport

Zadoya, K.P. (2015). Scientific and practical commentary to Article 369-3 of the Criminal Code of Ukraine «Illegal influence on the results of official sports competitions». Law and civil society, 2(11), 146-157. Retrieved from: http://lcslaw.knu.ua/index.php/ arkhiv-nomeriv/2-11-2015/item/219-naukovopraktychnyy-komentar-do-statti-369-3kryminalnoho-kodeksu-ukrayiny-protypravnyyvplyv-na-rezultaty-ofitsiynykh-sportyvnykh-zmahanzadoia-k-p. 